\title{
COVID-19 and Social Control
}

Prof. James J. Chriss, PhD

Department of Sociology and Criminology,

Cleveland State University, Ohio, USA

\section{Abstract}

The COVID-19 pandemic has once again brought into relief and tension the delicate balancing act modern governments must strike in assuring individual liberties of its citizens, while at the same time dealing with infectious diseases and other public health risks. It is not clear how best to strike this balance, or how to judge which countries are doing an adequate job and which others are failing (on either or both fronts). What is clear, however, is that by virtue of it being available to the state, public health is based not merely on medical expertise but also on power, insofar as it part of the regulative apparatus of the administrative state which can be implemented by decree at the behest of the executive.

Keywords: pandemic; public health; social control; law and politics; administrative law; separation of powers; Max Weber;Talcott Parsons; paradigms; knowledge and interests; Jürgen Habermas; Giorgio Agamben; history of medicine.

\section{Introduction}

On December 31, 2019, Chinese authorities alerted the World Health Organization to a number of pneumonia-related deaths of unknown origin, with the epicenter of the illness located in Wuhan City in the province of Hubei. It turned out to be a new strain of the coronavirus - which is of the same family as the common cold and various influenzas for which vaccines have been developed-and now identified as COVID-19. Since COVID-19 was a new strain of the virus for which a vaccine had not yet been developed, the world could only look on in horror as illnesses and deaths mounted as the virus was carried from China to other parts of the world. By early December 2020, the worldwide death toll from COVID-19 stood at 1.8 million with the number of infected at roughly 80 million. And by this time the U.S. figure had climbed to over $300,000 .^{1}$

Because of how rapidly and easily the virus is spread from person to person, in the United States and elsewhere many group activities-including sporting events-were shut down and persons who had to be in public (to get food, or for health reasons) were told to practice "social distancing," that is, as much as possible to stay at least six

\footnotetext{
${ }^{1}$ These figures are from https://coronavirus.jhu.edu/map.html.
} 
feet away from others. ${ }^{2}$ This also meant closing down many nonessential businesses such as malls, hair salons, bars and taverns, and the restaurants that remained open could only serve takeout or by drive through. This of course had serious economic ramifications, as jobless claims skyrocketed to a level not seen since the Great Depression, while the stock market and other financial institutions took a historical beating. In addition, schools and universities shut down and classes were converted to online instruction. Retail giant Macy's announced they would be furloughing 130,000 of their workers, producing a ripple effect of bad economic news across many sectors of society.

There was early speculation that COVID-19 emerged from wet markets in Wuhan, which are open-air markets where customers can shop for fresh meats, vegetables, and dairy products. But the wet markets per se were not the problem. Instead, there was some mixing of legitimate wet market activities with illegitimate wildlife market activities, whereby exotic animals like snakes and bats were introduced into these markets and infected some of the personnel and products that were otherwise legitimate. ${ }^{3}$

The COVID-19 pandemic is a good example of how social problems can spread rapidly and go global. The attempts to respond to conditions on the ground as they emerge in each local community creates a patchwork quilt of social control policies whose interventions target social, legal, and medical aspects of the pandemic. For example, on the social or interactional level, federal and local government informed persons that they should stay home and, when out, engage in social distancing. They should also wash their hands thoroughly (at least 20 seconds) and use (if available) hand sanitizer. On the medical side, public health officials scrambled to provide medical guidelines regarding symptoms, where to go to get tested, and describing the most vulnerable populations (the elderly and patients with underlying medical conditions). Finally, the legal side of control is made operative in a major way, mainly through disaster declarations, decisions to quarantine, and other powers vested in the executives at various levels of government, for example, requiring businesses to shift production and engineering capabilities to produce more protective gear for medical personnel but also ventilators for critically-ill patients.

\footnotetext{
${ }^{2}$ The emergence of the idea of social distancing as a result of the COVID-19 pandemic is indeed curious from a sociological perspective. In 1924 sociologist Emory Bogardus developed a so-called social distance scale, which purports to measure how close people are to others in their social relationships, studying how race, social class, gender, and income affect how close or distant such relations are (see Wark and Galliher, 2007). What is referred to as social distancing as applied to COVID-19 is not social distancing at all, but rather geographical or spatial distancing (that is, propinquity) which carries no specific sociological relevance.

${ }^{3}$ This situation is discussed in a Los Angeles Times story. See https://www.latimes.com/food/story/2020-03-11/coronaviruschina-wet-markets.
} 


\section{Lockdowns}

Stay at home orders promulgated by executive fiat raise anew questions concerning the constitutionality of such orders, especially as they necessarily curtail personal liberties in the name of public safety. As lockdowns continued through December 2020, many persons became restless and started staging political protests, while others opened their businesses in defiance of executive orders that shuttered such "nonessential" businesses as barbershops, hair salons, gyms, restaurants and bars, and furniture and clothing stores. When the governor of Wisconsin attempting to extend the stay at home order he had originally declared in March, the Wisconsin Supreme Court declared the extension to be an unlawful restriction on personal liberties. ${ }^{4}$ Additionally, in late 2020 the U.S. Supreme Court ruled that New York Governor Andrew Cuomo's restrictions on in-person religious gatherings were unconstitutional because such restrictions were harsher than those of comparable gatherings without providing the legal reasoning for such exclusivity. ${ }^{5}$ The ruling amounted to the unconstitutionality of the executive order because of the way it violated the First Amendment rights of religious worshippers, and that there are limits to the restrictions than can be placed on lawful activities even during a pandemic.

This issue of executive orders, especially when they involve the curtailing of liberties in the name of public safety or health, gets to the heart of conceptualizing and analyzing social control in its various forms. Decades ago, German political theorist Carl Schmitt 2007 [1932] defined the sovereign (or the executive) as "he who decides on the exception." So this gives the executive an extralegal and even extraconstitutional avenue for acting unilaterally, even while other branches may move to check the emergency declaration (such as what happened in 2019 when President Donald Trump diverted money to build his wall on the southern border, claiming it to be an emergency). Stay at home orders are basically house arrest. Under standard criminal justice procedures, house arrest is the punishment for someone already convicted of a crime. But a stay at home order is a proactive strategy that doesn't require a crime; indeed, it is close to the pre-crimes conceptualized by Philip K. Dick and made into the movie Minority Report. People could easily make this out to be yet another version of totalitarianism, of a Big Brother, nanny state curtailing liberties for the sake of public health, public safety, or whatever (Orwell's 1984). Both sides of the political divide can claim totalitarianism. It speaks to the existence of a hyperpartisan political divide in which persons of one political persuasion (whether Democratic or Republican) are likely to view the actions of the executive from the other political party (whether at the federal, state, or local level) as an unconstitutional power grab.

\footnotetext{
4 For more on this story, see https://abcnews.go.com/US/governor-urges-social-distancing-wisconsin-court-blocks-stay/ story?id=70683102.

${ }^{5}$ For more on this story, see https://www.nytimes.com/2020/12/01/opinion/supreme-court-Covid-19-religion.html.
} 
We see, then, that the power of the state can be brought to bear against anyone by the executive in the declaration of an emergency, which suspends the operations and constitutional safeguards normally in place. On Tuesday, December 8, 2020, 25-year-old Klodian Rasha was killed by police for violating an overnight curfew imposed because of a recent escalation of COVID-19 cases in Tirana and across Albania. ${ }^{6}$ Initial reports were that Rasha failed to obey orders to stop and that police believed he was carrying a weapon (which he was not). The next evening protests broke out over the police shooting. Government buildings were damaged while a number of protestors and police officers were injured.

Although ideally public health is "the art and the science of preventing disease, prolonging life, and promoting health" (Weisheit and Klofas 1998, p. 198), because it operates at the behest of government it is first and foremost animated and prescribed by the use of force or its threat. That is to say, like all elements of government, the primary delinguistified, circulating medium that makes public health what it is, is power (Parsons, 1963), not altruism, cognitive rationality, science, or other lofty or noble attributions. ${ }^{7}$ Like money in the economy and influence in everyday life (or the lifeworld), power is a circulating medium of interchange which allows its possessor to effectively discharge responsibilities in office or some specific status (whether legislator, executive, doctor, father, etc.; see Parsons, 1966). Hence, power is a relational concept and not merely a unilateral "power to" or "power over," to the extent that rational authority bestows upon functionaries of government in various administrative spheres-including that of public health-the right to pursue system goals presumably for the benefit of the collectivity (Haugaard, 2013).

This means as well that public health cannot escape the political elements present in its operation and core existence. Although traditional medicine does indeed have elements of governmental oversight and steering, particularly with regard to educational requirements and state licensing and certification of practice, the traditional doctor-patient relation is guided by scientific expertise whereby clients or customers are free to enter markets and choose providers as they see fit (Lidz, 2010). Traditional medicine in the doctor-patient relationship is "off the books" and relatively invisible to the state, that is, it is guided largely by the "ought" of morality part and parcel to the operation of informal control. When medicine and medical practice are coupled to the mandates of law and defined within a broader social public policy matrix, as is the case for public health, then it invariably becomes potentially more

\footnotetext{
${ }^{6}$ This report is located at https://www.thejakartapost.com/news/2020/12/10/albanians-protest-after-police-shoot-dead-manfor-violating-covid-19-curfew.html.

' I cannot get into details here, but the concept of circulating media is an analytical innovation within the development of Parsons' AGIL or four-function schema. As I describe them, the media of interchange are “...crucial resources or elements seated within particular systems or subsystems of society that circulate throughout the system (or pertinent subsystem) in order to allow units or features of the system to fulfill their functions for the broader society" (Chriss, 2016a, p. 65).
} 
coercive and punitive in order to give it "teeth" to accomplish tasks above those of providing medical care for patients on a case by case basis.

Indeed, a large literature has emerged especially in the context of western society generally and the United States specifically, of the growth of an intrusive, cradle-to-grave Nanny State whereby the dictates of experts (see Turner, 2003) guide medical interventions for the presumed good of hapless citizens whose lifestyles are suboptimal for, or perhaps even detrimental to, health. Public health, then, would be akin to a father attempting to coax his son or daughter into drinking a noxious-tasting medicine "for their own good." Within this context, public health is state paternalism, a version of parens patriae, that is, the state as parent (see Platt, 2009). This is the idea of the enlightened professional bureaucrat who makes possible the coupling of scientific expertise to social policy which, in its most ideal rendering, would get us close to Lester F. Ward's (1883) declaration that the ultimate end of applied sociology is the production of "attractive legislation." Even so, within this context there is a tendency to view citizens as childlike and hopelessly misinformed, and that they cannot be left to their own devices because they will often make bad if not disastrous choices which will harm not only themselves but a large swath of the general public.

To reiterate, public health officials are not merely applying scientific principles in a sober and dispassionate manner to ameliorate harm and to shore up the public welfare. That is to say, politics is always, albeit to varying degrees, entangled in public health issues of the day. For example, with regard to the COVID-19 pandemic we heard the mantra quite often in the mainstream media that we should "listen to the science" in terms of our own personal conduct-wearing masks, washing hands regularly, and social distancing-as well as the public postures of pundits, politicians, and legislators who are urged to maintain fidelity to authoritative scientific findings. However, any public statement or action related to COVID-19 has the potential to be politicized, and much of this has to do with the organization of public health itself, lodged as it is within the bureaucratic structures of government at federal, state, county, and local levels.

In addition, the COVID-19 pandemic appeared at a time when American politics is deeply divided and hyperpartisan. Indeed, this hyperpartisanship between left and right has been growing since the early 2000s with no sign of abating (Chriss, 2018). A few months after the 9-11 terrorist attacks, President George Bush proclaimed that "You're either with us or against us in the fight against terror." ${ }^{8}$ This sentiment fits neatly into Schmitt's (2007 [1932]) definition of the political as "friends vs. enemies." It is an extension and even radicalization of Weber's (1968 [1920], p. 54) lament that politics is the preeminent struggle for existence, as he defined the state as a "compulsory political organization with continuous operations...insofar as its administrative staff

\footnotetext{
${ }^{8}$ See the CNN report at https://edition.cnn.com/2001/US/11/06/gen.attack.on.terror/.
} 
successfully upholds the claim to the monopoly of the legitimate use of physical force in the enforcement of its order." For Weber, the essence of politics is struggle, and indeed, the political order rests on violence (Swedberg, 1998, pp. 57-58).

Connected with this, rather than an economic approach to explaining the modern city (polis), Weber argued for the political aspects of this development. To wit, the development of settled communities meant that in large measure cities were fortresses which sought to protect the resources they had developed and accumulated against interlopers or free riders who did not contribute to their production and who had no rightful access to them (Swedberg, 1998, p. 71). The state configuration, and especially the invention of the citizen, is merely an enlargement and expansion of this friend-enemy (us-them, lawful-unlawful) distinction.

Shortly after COVID-19 attracted worldwide attention, George Floyd died while in police custody in Minneapolis, and society has never been quite the same since. The video of Officer Derek Chauvin with his knee on Floyd's neck for upwards of eight minutes appalled the world. Many cities erupted not only into protest-mostly peaceful-but also violence, looting, and property destruction. The group Black Lives Matter achieved a much higher profile, and some cities painted murals on streets and elsewhere with the BLM logo. And a two-block-long section of downtown Washington, DC was renamed Black Lives Matter Plaza.

In June 2020, a group of over 1,000 health professionals released a letter urging city leaders not to use coronavirus restrictions to shut down these anti-racism and social justice protests. A key passage from that letter reads as follows:

However, as public health advocates, we do not condemn these gatherings as risky for COVID-19 transmission. We support them as vital to the national public health and to the threatened health specifically of Black people in the United States. We can show that support by facilitating safest protesting practices without detracting from demonstrators' ability to gather and demand change. This should not be confused with a permissive stance on all gatherings, particularly protests against stay-home orders. ${ }^{9}$

Here, public health officials are clearly taking sides politically, lauding some protests while denouncing others. In reality, a purely scientific approach to this issue would admit that COVID-19 doesn't care why people are gathering. The letter writers specifically targeted as condemnable protests against lockdowns or stay-home orders. But recent research is indicating various detrimental health effects of such lockdowns. For example, lockdowns as a strategy to curb the spread of COVID-19 infections pose grave risks to the nutritional status and survival of children in low- and middle-income countries, particularly in the hardest hit areas of sub-Saharan Africa and south Asia

${ }_{9}$ The full letter is available at https://www.cnn.com/2020/06/05/health/health-care-open-letter-protests-coronavirus-trnd/ index.html. 
(Standing Together for Nutrition Consortium, 2020). And with many schools suspending in-person classes, virtual learning via Zoom and other platforms has effectively left behind vast numbers of students, with a disproportionate number of them from Black, Latino, and Native American households. ${ }^{10}$ Additionally, there is growing evidence that the isolation caused by COVID-19 pandemic restrictions is leading to declines in mental health including increases in substance use and suicidal ideation (Czeisler et al., 2020). Connected with this, the Blue Cross Blue Shield Association surveyed millennials-persons born between 1981 and 1996-in September 2020 and found that $92 \%$ of them reported that their mental health had worsened as a result of the pandemic, while $34 \%$ reported an increase in alcohol consumption. ${ }^{11}$ And of course, the shutting down of small businesses falling into the category of "nonessential" has put millions of people out of work, with many of these businesses unlikely to reopen. ${ }^{12}$ Some could actually interpret this as not all that bad or evil, insofar as a radical critique of capitalism has been its unending and insatiable need to continue to expand consumption and channel desire to prod people into commodification of all things, now secured under neoliberalism (see Musaraj, 2020).

\section{Science and Dogmatism}

During the COVID-19 pandemic, there has been a tendency for shrill assertions about the infallibility of science, when in fact, real science is best described as "organized skepticism" (Merton, 1968). Organized skepticism does not mean being open to any claims regardless of how fanciful or remote from reality they might be. Rather, organized skepticism is the stance of not rejecting claims out of hand and allowing possibly outlier claims to be dealt with according to the standard protocols of the scientific method. Consistent with this is the concept of falsifiability, namely, that because we often do not have all facts at hand by which to assess the veracity of claims, the best we can do is attempt to falsify hypotheses through crucial tests. Although it is a noble goal to attempt to verify current theories by comparing how well hypotheses derived from them comport with empirical reality, we must also admit that not all evidence for such confirmation is readily at hand, especially when the goal is the development of universal covering laws that purport to explain not only present phenomena but also those of the past (postdiction) and future (prediction).

\footnotetext{
${ }^{10}$ See the report at https://www.washingtonpost.com/education/a-national-crisis-as-coronavirus-forces-many-schools-onlinethis-fall-millions-of-disconnected-students-are-being-left-behind/2020/08/16/458b04e6-d7f8-11ea-9c3b-dfc394c03988_story. html.

${ }^{11}$ See this report at https://www.fiercehealthcare.com/payer/bcbsa-millennials-mental-health-decline-and-covid-19-making-itworse.

${ }^{12}$ As of December 2020, in New York City alone more than 1,000 restaurants and bars have closed and are not likely to reopen. As of June 2020, the restaurant and food service industries have lost $\$ 120$ billion due to the pandemic. See https://abcnews.go.com/ Business/restaurant-food-service-industry-lost-120b-due-pandemic/story?id=71301061.
} 
Instead of absolute confirmation, Popper (1945, p. 79) argues for falsification, stating that "...just because it is our aim to establish theories as well as we can, we must test them as severely as we can; that is, we must try to find fault with them, we must try to falsify them." ${ }^{13}$ This means that built into science is a stance of open and organized skepticism, whereby theories are taken at face value-rather than being dismissed summarily upfront-and exposed to such crucial tests to examine how well they are supported by data. Theories that survive such crucial tests, that is, those that are not falsified, count provisionally - in the here and now and for the time being-as good knowledge. But these theories are good only insofar as they continue to withstand crucial tests. Unlike ideologies which cannot be rationally adjudicated, and which tend toward dogmatism thereby closing off open and honest debate (Gouldner, 1974a), scientific claims must always be open to challenge and possible refutation. In our polarized and hyperpartisan modern world where people have been urged to filter reality through the primary prism of the political (for example, the mantra "the personal is political"), is it any wonder that political discussion on such topics (e.g., climate change, COVID-19, forced vaccinations or other medical procedures) invariably degenerates into the Schmittian friend-enemy distinctions of "alarmist" or "denier" depending on what side of the political divide you stand? (see Pérez-González, 2020; Turner, 2013)

The friend-enemy distinction is especially prominent in American politics regarding President Donald Trump, whose supporters view him as saintly and the defender of the American way, while detractors view him as a monster or an incompetent buffoon, or perhaps a little of both. Consistent with our previous discussion, during the COVID-19 pandemic shrill assessments have been made by the mainstream media, political pundits, journalists, and citizens identifying themselves as the "resistance" and occupying primary positions on social media, television, print media, and the blogosphere. Indeed, it is likely that dissatisfaction over his handling of the pandemic was the key factor in his defeat in seeking a second term of office.

An example that comes readily to mind was the controversy over Trump's touting the drug hydroxychloroquine as a potentially effective treatment for COVID-19. Trump announced he was taking the medication, and he urged that the drug be readily available to patients in consultation with their doctors to determine the appropriateness of the treatment. The media backlash against Trump was intense, and Twitter removed his tweets claiming the drug's effectiveness against COVID-19. ${ }^{14} \mathrm{~A}$ leading medical journal, Lancet, got into the act as well, claiming that the best "scientific" evidence determined that hydroxychloroquine was ineffective against COVID-19. Later, on June 5, 2020, Lancet had to retract the article because it was discovered that their presumably

\footnotetext{
${ }^{13}$ What this means in practice is that, rather than setting out to affirm a hypothesis, the goal is to reject the null hypothesis. For an extended discussion of the logic of falsification in the determination of statistical significance, see Chow (1998).

14 See https://www.nbcnews.com/politics/donald-trump/twitter-removes-tweet-highlighted-trump-falsely-claiming-covidcure-n1235075.
} 
authoritative position was based on questionable data from suspect sources (Mehra et al. 2020). Trump's supporters were absolutely giddy with glee over this epic fail, and it helped to reaffirm that at least some of the claims being made about the science of COVID-19 were motivated in equal measure by ideology and politics. ${ }^{15}$ And of course this fed into and sustained the friend-enemy distinction.

\section{More on Social Control}

But why should any of this be a surprise to anyone? When it comes to government, politics is entangled in everything it does, including public health. It is primarily a question of social control, and it is important to distinguish between three major types: informal, legal, and medical (Chriss, 2013). ${ }^{16}$ Informal control is the most ancient of the three forms, as this involves the tacit, background assumptions of propriety that arises in any particular human group. Norms of conduct- "folkways" according to Sumner (1906)-emerge slowly over the course of natural and social evolution, and this early form of self-policing creates solidarity of the local clan or tribe whereby relationships formed within the group maintain the peace in the production of norm-conforming behavior. Within informal control, the primary medium circulating throughout the system to maintain group solidarity is influence.

Over time, as social life becomes settled and technologies are developed in food quests and other areas, populations increase as well as anonymity, hence the predictability of conduct previously assured through likeness and familiarity are eroded, giving rise to more formal types of control. The two most prominent of these are law and medicine, and as societies reach more advanced stages of development new social structures emerge, the most important of which are imperatively-coordinated associations (or ICAs; Weber 1968 [1920]). At the stage of societal development associated with the demise of nomadism and the settling of land, ruling systems not only become textualized (into legal codes and statutes), but the implementation and enforcement of these laws are given legitimacy via the anchoring in state bureaucracy (Chriss, 2020a). It is here, with the birth of the state, that the ICA reaches its most elaborate and expansive development, representing the institutionalization of the cultural ideals, role relations, and social structures which endow leaders (kings or executives) with the power to direct a staff of officeholders to carry out enforcement and regulatory functions for the state (Weber 1968 [1920]). This is consistent with our earlier discussion of Weber's view of the state, as the premier ICA regulating conduct within a jurisdiction through the use of force

\footnotetext{
${ }^{15}$ See, for example, the opinion piece published in the Wall Street Journal, written by Marc Chafetz, in which he congratulates the newspaper for correctly questioning the legitimacy of the Lancet article: https://www.wsj.com/articles/political-bias-the-lancetand-coronavirus-11591562091.

${ }^{16}$ There is a fourth major type of social control according to Talcott Parsons, namely, religious control. Although I am unable to go into details here, I (Chriss, 2020b) explain how Foucault's concept of pastoral power can be coupled to Parsons' AGIL schema to create a new functional theory of religious social control.
} 
or its threat. Whereas the circulating medium operative within everyday life (informal control) is influence, for the state and law the operative circulating medium is power.

Medicine grows out of the earliest stages of human development where mysticism and magic endow possessors with healing powers to administer to the sick and dying while also protecting the living through appropriate rituals and incantations. The most well-known figure in early medical practice was the shaman, who was adept at knowing the properties of local flora and fauna and utilizing them to administer health and other benefits to the indigenous group. The history of the study of the shaman as the central character in the development of early medicine is now largely discussed within the subfield of ethnomedicine (Green, 1998), and one trend of late within this field is overcoming the invidious distinction between earlier "primitive" medical practices and later "modern" medicine as it has become fully institutionalized and aided by technological breakthroughs with regard to medicine and therapeutics, all of which is overseen by rigorous training and licensing of practitioners as mandated by the state. Although this is all well and good, any authentic history of the development of medicine from earliest times to the present would confirm the presence of the belief in magic in shamanic practice while acknowledging how over time this belief has waned in the context of later medical practice.

Lester Ward's (1883, vol. 1) discussion of the fear of disease is especially useful for our purposes. ${ }^{17}$ Along with the fear of personal violence, which has been characteristic of humanity since antiquity, there has always been a deep-seated dread of bodily disease. Not yet possessing the knowledge of the human body and its organs or the role of pathogens in transmitting disease, early humanity explained those calamities that befell human populations outside the context of visible physical assault or accidents, to demonic forces or possession. There is also early animism associated with this demonic theory of disease, as early humans attributed agency, cunning, and guile to objects, whether animate or inanimate, that were thought to be the source of such misery, calamity, illness, or death. A fear as powerful as this, so widely believed and felt, would obviously bring to the fore individuals who promised to relieve people's misery. Hence ceremonies and rituals were developed, with shamans leading the way, promising to supply remedial substances to cure and to protect. Over time, of course, the ceremonial gave way to the more rational with the systematic development of such sciences as botany, chemistry, and biology and their application to the human body under the sciences of anatomy, physiology, and hygiene (Ward, 1883, p. 689).

During Medieval times (roughly 1347-1352), the Black Death (or the bubonic plague) swept across Eurasia and North Africa, killing upwards of 50 million people (Alfani and Murphy, 2017). In England, the Black Death coincided with the Peasants' Revolt, and this

${ }^{17}$ Although there are some variations, Ward's discussion is consistent with Herbert Spencer's (1897) general theory of fear and, specifically with regard to medicine, the supernatural origin of disease. 
introduced a political-specifically, a class-element into the medical response. English leaders and landlords were not only worried about the possibility of unrest and violence over the labor dispute, they were also worried that poor and itinerant laborers facing unemployment or reduced wages because of the pandemic would be moving about the countryside unchecked. Soon this cultural attitude would receive legal backing, to the effect that able-bodied persons who were idle or refused to work would be compelled to labor or be fined or sanctioned even more severely if found guilty. New terms and new legal categories such as "nightwalking," "vagabonds," "vagrants," and "beggars" were created (Chambliss, 1964). Indeed, during this time vagabonds traveling on the roads without evidence of gainful employment were assumed to be transmitters of disease (McIntosh, 1998, pp. 90-91). These were the beginnings of new social and legal approaches to dealing with the transient poor, and many of these activities created frameworks for the later development of public health which became institutionalized in England and the United States in the nineteenth century (Slack, 2020).

Where power is the operative media for legal control and influence the media for informal control, for medical control it is capacities (Parsons, 1964). Within the social system, persons act on the basis of expectations institutionalized within the status-role system. For example, while occupying the status of father I should take an expressive rather than an instrumental orientation toward family members, and within that same family unit children occupying the status of daughter or son are expected to listen to their parents. Indeed, if socialization goes according to plans and parents act toward children in ways perceived to be in alignment with cultural values regarding parental responsibilities of care, compassion, custody, and guidance, children view their parents as role models, that is, are influenced by them (Chriss, 2019). ${ }^{18}$

This is the operation of influence within informal control, and it works when persons in relationships with others-whether in primary or secondary group settings-have the capacity to carry out the social roles assigned to them. But when persons are ill, they lack either physical or mental capacities to meet social obligations, creating a disturbance within their relationships. But unlike deviants who disregard informal norms of loyalty or influence in everyday life (in informal control) or who disregard or violate laws (in legal control), persons under the auspices of medical control are unable to conform to expectations for conduct because they lack the capacity to do so (Varul, 2010). Hence, although punishment is the expected sanction for deviance in the informal and legal realms, in the medical realm treatment or therapy is the expected sanction because the ill are held blameless for their bad acts.

\footnotetext{
${ }^{18}$ This describes the ideal operation of the socialization process within primary group settings such as the family. But, of course, conflict, disruption, and disorder can occur, including disagreements over values and how to interpret them. For an examination of the threats to family harmony and social control in the specific case of teen sex and pregnancy, see Mollborn (2017).
} 


\section{Public Health and Politics}

As we have seen, public health is a hybrid project of social control bringing together the circulating media of capacities from medical control and power from legal control. That is to say, the state appropriates medical expertise and uses it to develop medical policies and regulations via administrative law. In this way, the state gives "teeth" to medical judgments that under non-state circumstances-for example, in the doctorpatient relationship-would not act as intrusively or compulsively. Law and regulatory rulings bank on power to mandate outcomes even in the face of resistance, whereas in both everyday life and in private medical practice-especially in those situations where persons voluntarily seek medical opinions or procedures-there are greater opportunities for negotiation. And even if disputes arise or norms are violated, the sanctions to be meted out are of a fundamentally different type than those of legal control.

In addition, by virtue of the state utilizing power to mandate outcomes related to health and medicine, public health is shot through with politics just as are other projects of state administration (such as criminal justice, juvenile justice, business administration, forest management, labor relations, homeland security, and so forth; see Sheptycki, 2020). Foucault (1977, p. 144) put this well in the context of his discussion of the apparatus of the carceral state: "The medical supervision of diseases and contagions is inseparable from a whole series of other controls: the military control over deserters, fiscal control over commodities, administrative control over remedies, rations, disappearances, cures, deaths, simulations."

More than other types of law, administrative agencies and their regulatory rulingsnot technically laws, because under constitutional nondelegation these are the sole province of the legislature-are under the auspices of the executive who names persons to regulatory boards and can fire them as he sees fit in most circumstances (Hamburger, 2014). Administrative agencies are executive agencies insofar as regulation is a type of enforcement, and of course according to the U.S. Constitution's separation of powers, the executive branch enforces the law, the legislative branch enacts or creates law, and the judicial branch interprets law. All this points to the observation that the growth of administrative law redounds to the glory and the power of the president, and the president is the premier political actor of the federal government (Chriss, 2020a). ${ }^{19}$

\footnotetext{
${ }^{19}$ Even while the growth of administrative law increases the power of the president, it simultaneously increases the power of the civil servants of the federal bureaucracy, which during the Trump Administration was pejoratively designated as the Deep State which collectively joined the resistance against Trump's policies. Max Weber was prescient on the issue of bureaucratization and political leadership, and as Weber scholar Reinhard Bendix (1962, p. 439) noted, "Thus politicians contend for leadership not only in elections and in legislation but with the bureaucracy."
} 
This moves us perilously close to the proclamation that "Everything is political!" (see Chriss, 2015). This is the position of Marxist literary critic and scholar Fredric Jameson (1981, p. 20), who states that everything is essentially political. He also believes that all reading and textual interpretation - that is, hermeneutics - can only be successfully carried out within the Marxist framework of historical materialism. And even if one claims to be acting apolitically, Jameson appropriates Freud's unconscious and weds it to the Marxist notion of "false consciousness," and in so doing breaks the bad news to everyone that they possess a "political unconscious" whether they know it or not. This is the idea of structuralism, namely, that deep, latent, or even invisible elements are the engine generating and propping up observable phenomena (Gouldner, 1974b; Levi-Strauss, 1949). This also serves as a handy critique of positivism and the empirical sciences which are labelled "bourgeois."

A less strident Marxist, Jürgen Habermas $(1971,1973)$, had earlier covered some of the same material as Jameson but, regarding the question of the unity of theory and practice, he was willing to say only that there is a connection between knowledge and interests. ${ }^{20}$ Habermas $(1973$, p. 8$)$ stated that "There is a systematic relationship between the logical structure of a science and the pragmatic structure of the possible applications of the information generated within its framework." Specifically, there are three distinct categories of processes of inquiry illustrating the connection between logical-methodological rules (knowledge) and knowledge-constitutive interests (Habermas, 1971, p. 308). First, the standard positivist or empirical sciences, which stress quantitative methods and the development of deductive-nomothetic (that is, causal) theory, are associated with technical cognitive interests, namely, the control of empirical reality for purposes of explanation, prediction, or postdiction, all the while maintaining adequate distance between researchers and subjects so as to assure the production of objective or value-free knowledge. Second, the historical-hermeneutic sciences which, in seeking understanding rather than explanation, incorporate practical interests to the extent that such researchers reduce distance between themselves and subjects to understand how fellow human beings interpret their world and create meaning through exchange of significant symbols. Third, the critically-oriented sciences incorporate an emancipatory interest, seeking to eliminate oppression or inequality by identifying and dismantling structures, cultures, or practices of domination, the overall project of which is essentially political.

These three interests-technical, practical, and emancipatory-align remarkably well with Helmut Wagner's (1963) identification of three distinct paradigms within sociology (listed below along with the major goals of each):

- Positivist - to discover the laws of society (Habermas' technical interests)

${ }^{20}$ Predictably, Jameson (1981, p. 100) slams Habermas for subsuming the Marxist model of production under his all-encompassing theory of communicative action. 
- Interpretive - to learn how persons make the social world meaningful (Habermas' practical interests)

- Evaluative - to change the social world (Habermas' emancipatory interests; for a summary, see Chriss, 2016b)

Wagner's position on the three paradigms was that the positivist and the interpretive are true sciences to the extent that they seek to explain "what is," while the evaluative paradigm is more interested in "what ought to be" - the four most prominent theories being variants on humanitarian-political reform, namely, Marxism, feminism, critical race theory, and queer theory-through an imminent critique of existing social arrangements and pursuing a normative agenda which is unabashedly political. Over time, however, the positivist claim that objective knowledge of the social world is attainable through diligent commitment to the protocols of scientific method which weeds out systematic bias (whether ideological, political, personal, economic, or what have you), and which thereby delivers objective and interest-free knowledge, was more fanciful than real. Habermas' contribution was a soft form of unmasking, acknowledging that all three approaches are wedded to imminent interests, although even from this reading one could still claim that only the evaluative paradigm, with its goal of emancipation for the downtrodden and oppressed, is truly political. ${ }^{21}$

There are two strategies that can be pursued by those critical of the claim that sociology can produce objective knowledge free of ideological or political distortions (Baehr, 2019). One, critics can claim that positivists and other defenders of value-free knowledge are hypocrites, in that they, too, hold to extra-scientific or ideological ideas which invariably enter into their theoretical work. This is similar in ways to the sort of unmasking done by Husserl (1970) and the phenomenologists, who argue that scientists' claims of explaining phenomena in their true or pure essence cannot be sustained insofar as all humans are immersed in a pre-existing lifeworld in which tacit, background understandings of how the world works-which amounts to the natural attitude-are unwittingly brought into their so-called "scientific" theories. The only way to gain purchase on the explanation of true phenomena is to bracket out this natural attitude through the phenomenological ह̇ंoxń or reduction.

A second, more radical approach, is to claim not only hypocrisy on the part of positivists, but also that they possess concealed interests and are acting in bad faith. Again, this gets us back to the argument that by virtue of being human, our ideas and beliefs are through and through ideological or political, and any sensible person understands this. Barry Barnes $(1977$, p. 33) argues that knowledge or culture "...is ideologically determined insofar as it is created, accepted or sustained by concealed, unacknowledged, illegitimate interests." Barnes does admit, however, that there are

${ }^{21}$ For a systematic analysis of the unmasking style in sociology and social theory, see Baehr (2019). 
no objective standards by which to establish that such concealed interests are actually present in the person to whom you are ascribing them. And further, even if somehow it could be shown that person $X$ actually did possess concealed interests $Y$, it is difficult to state definitively what the effect of those concealed beliefs actually were on some area of reality. Of course, Barnes is correct: This is how ideology and politics work.

\section{Conclusion: Agamben, Law, and Life}

This is an easy charge to make, and so we come full circle in our discussion of the status of public health and social control in the COVID-19 pandemic. In making such a claim, one opens oneself to criticisms that one is acting in a dangerously flippant manner regarding the actual evidence of the destructiveness of the disease, as for example, the grim reality of the United States' COVID-19 tally which has surpassed 300,000 deaths. Because opinions on the pandemic are so highly-charged and militant, reactions against persons perceived as not bowing to consensus-popular, scientific, or political-take predicable routes. The example I will close with here is what happened to the highly-renowned Italian philosopher, Giorgio Agamben, when he published some commentary on the pandemic back in its early stages.

Agamben took positions in a few areas that ruffled a lot of feathers. For example, he bemoaned the ongoing secularization of society and the general waning of religious affect. But, as the COVID-19 pandemic demonstrates in terms of the panic that ensued, we have merely replaced traditional religion with a new religion, the religion of science. Indeed, Agamben referred to healthcare under the public health reaction as "health scare." Just as priests from the pulpit put the fear of God in true believers, public health officials, supported by compliant media commentators, put the fear of COVID-19 in citizens.

Another position staked out was that, as persons seemed content to accept the limitations and lockdowns imposed to keep the disease from spreading, this seemed to Agamben to provide yet more evidence that an attitude toward bare life-mere animal or vegetative existence-had already taken root in modern society and was expanding and being further exploited as the result of the pandemic. When humanity lived in its primitive state, that is, in the state of nature, life was a desperate struggle for survival, and not much differentiated the human species from animals. Drawing from Aristotle, Agamben (2016) refers to this type of living as "bare life," designated by

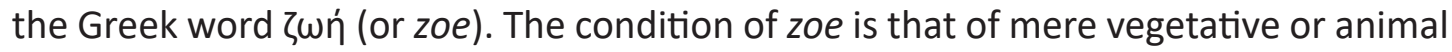
existence, where all energies and goals are directed by the survival instinct. 
Over time, with advances in human development including the movement from a largely nomadic to a sedentary existence, human beings escape the state of nature and learn how to live together in settled communities (the polis) according to the tacit or codified rules of the broader political organization developed locally. In the transition from the early, pre-political life (zoe), humanity now enters civilization, the political community, designated by the Greek word ßıৎ (or bios; see Agamben, 2016). In this elevated life, persons who are fully ratified members of the community (namely, citizens) are relatively assured various levels of security (physical, economic, cultural, and psychological) and are able to turn their attention away from concerns over mere survival to social and cultural activities available to members of the local community.

Law is a greedy institution, meaning that more and more areas of social life become juridified and subject to scrutiny and oversight by the government (Chriss, 2020a). In the early stages of the transition from zoe to bios, the legal system treated individual human beings as virtually invisible save for areas in which they were accountable to the state, such as in the areas of taxation, conscription, mandatory schooling, passports, birth and death records, and so forth. This meant that aspects of bare life were left alone, as the state focused more on broader political, social, and cultural characteristics of populations and the civil life of the community writ large (and indeed, there is a separation of the civil sphere or the lifeworld from the state or the system; Habermas, 1987).

However, consistent with Foucault's (2007) notion of governmentality, from the nineteenth century onwards and with the rise of the human, social, and behavioral sciences, persons' bodies and their functioning - and hence new attributions of normal and pathological-started becoming objects of interests to the state. There emerged a new configuration of disciplinary authority whereby experts in various of these fields successfully coupled knowledge to power and made it available to the state, including data about persons' sexuality, identity, weight, friendship networks, political attitudes, religious affiliations, and so forth. This means that states have returned with a vengeance to a concern with bare life. For example, concerns over climate change have prodded some governments to institute or propose carbon taxes to offset the damage done to the ecosystem because of the release of carbon dioxide by animal organisms. Hence, the very act of coming into existence-living and breathing-can fall under the spell of juridification with law's growing attention to zoe (Agamben, 1998).

Here is one of Agamben's quotes that created significant pushback from critics:

The first thing that the wave of panic that has paralyzed the country obviously shows is that our society no longer believes in anything but bare life. It is obvious that Italians are disposed to sacrifice practically everything-the normal conditions of life, social relationships, work, even friendships, affections, and religious and political 
convictions - to the danger of getting sick. Bare life-and the danger of losing it-is not something that unites people, but blinds and separates them (Agamben and Kotsko, 2020, p. 3).

I leave it to the reader to decide whether Agamben is off base here, and if he is, how far off base he is. I am of the opinion that scholars as important as Agamben need to be given wide latitude concerning their observations about current events. Voices in the wilderness are worth listening to and are often right to boot.

\section{Bibliography}

1. Agamben, Giorgio. 1998. Homo Sacer: Sovereign Power and Bare Life, translated by D. Heller-Roazen. Stanford, CA: Stanford University Press.

2. Agamben, Giorgio. 2016. The Use of Bodies, translated by A. Kotsko. Stanford, CA: Stanford University Press.

3. Agamben, Giorgio and Adam Kotsko. 2020. "Giorgio Agamben on Health Scare and the Religion of Science." Inscriptions vol. 3, article 72 (July 2020):1-5.

4. Alfani, Guido and Tommy E. Murphy. 2017. "Plague and Lethal Epidemics in the Pre-industrial World." Journal of Economic History 77 (1):314-343.

5. Baehr, Peter. 2019. The Unmasking Style in Social Theory. New York: Routledge.

6. Barnes, Barry. 1977. Interests and the Growth of Knowledge. London: Routledge \& Kegan Paul.

7. Bendix, Reinhard. 1962. Max Weber: An Intellectual Portrait. Garden City, NJ: Anchor Books.

8. Chambliss, William J. 1964. "A Sociological Analysis of the Law of Vagrancy." Social Problems 12 (1):67-77.

9. Chow, Siu L. 1998. "Précis of Statistical Significance: Rationale, Validity, and Utility." Behavioral and Brain Sciences 21:169-239.

10. Chriss, James J. 2013. Social Control: An Introduction, $2^{\text {nd }}$ ed. Cambridge, UK: Polity.

11. Chriss, James J. 2015. "Social Marketing as Social Control." Pp. 151-174 in Handbook of Persuasion and Social Marketing, edited by D.W. Stewart. New York: Praeger.

12. Chriss, James J. 2016a. "The Expressive Revolution and the University: Parsons vs. Gouldner." Pp. 55-71 in Anthem Companion to Talcott Parsons, edited by A.J. Treviño. London: Anthem Press.

13. Chriss, James J. 2016b. Confronting Gouldner: Sociology and Political Activism. Chicago, IL: Haymarket Books. 
14. Chriss, James J. 2018. "Political Violence in Historical Perspective." Pp. 10151029 in Sage Handbook of Political Sociology, edited by W. Outhwaite and S. Turner. London: Sage.

15. Chriss, James J. 2019. "Social Control: History of the Concept." Pp. 9-22 in Handbook of Social Control, edited by M. Deflem. Hoboken, NJ: Wiley Blackwell.

16. Chriss, James J. 2020a. Law and Society: A Sociological Approach. Thousand Oaks, CA: Sage.

17. Chriss, James J. 2020b. "Religion as Social Control: Parsons and Foucault." Interdisciplinary Journal of Research on Religion 16 (7):1-46.

18. Coppola, M., Immacolata, S., \& Masullo, G. (2020). Parents in Pandemic: parents' perceptions of risks and psychological, relational, and pedagogical needs in childhood during the COVID-19 emergency in Italy. Academicus International Scientific Journal, 22.

19. Czeisler, Mark E. et al. 2020. "Mental Health, Substance Use, and Suicidal Ideation During the COVID-19 Pandemic-United States, June 24-30, 2020." Centers for Disease Control and Prevention, Morbidity and Mortality Weekly Report, vol. 69. N. 32, pp. 1049-1057.

20. Foucault, Michel. 1977. Discipline and Punish, translated by A. Sheridan. New York: Vintage Books.

21. Foucault, Michel. 2007. Security, Territory, Population, translated by G. Burchell. New York: Picador.

22. Ferrarotti, F. (2011). Bismarck's Orphan: The Modern World and Its Destiny, from "Disenchantment" to the "Steel Cage". Academicus International Scientific Journal, 2(04), 11-34.

23. Gouldner, Alvin W. 1974a. "Marxism and Social Theory." Theory and Society 1 (1):17-35.

24. Gouldner, Alvin W. 1974b. "The Metaphoricality of Marxism and the Contextfreeing Grammar of Socialism." Theory and Society 1 (4):387-414.

25. Greene, Shane. 1998. "The Shaman's Needle: Development, Shamanic Agency, and Intermedicality in Aguaruna Lands, Peru." American Ethnologist 25 (4):634658.

26. Habermas, Jürgen. 1971. Knowledge and Human Interests, translated by J.J. Shapiro. Boston: Beacon Press.

27. Habermas, Jürgen. 1973. Theory and Practice, translated by J. Viertel. Boston: Beacon Press.

28. Habermas, Jürgen. 1987. Theory of Communicative Action, vol. 2, translated by T. McCarthy. Boston, MA: Beacon Press. 
29. Hamburger, Philip. 2014. Is Administrative Law Unlawful? Chicago, IL: University of Chicago Press.

30. Haugaard, Mark. 2013. "Power and Hegemony." Pp. 239-255 in Sage Handbook of Power, edited by S.R. Clegg and M. Haugaard. Los Angeles: Sage.

31. Husserl, Edmund. 1970. The Crisis of European Sciences and Transcendental Phenomenology, translated by D. Carr. Evanston, IL: Northwestern University Press.

32. Jameson, Fredric. 1981. The Political Unconscious: Narrative as a Socially Symbolic Act. Ithaca, NY: Cornell University Press.

33. Levi-Strauss, Claude. 1949. Les Structures Elementaires de la Parente. Paris: Presses Universitaires de France.

34. Lidz, Victor. 2010. "Social Control in Doctor-Patient Relationships: Similarities and Differences across Medical Specialties." Pp. 149-169 in Social Control: Informal, Legal and Medical, edited by J.J. Chriss. Bingley, UK: Emerald.

35. Mclntosh, Marjorie Keniston. 1998. Controlling Misbehavior in England, 13701600. Cambridge, UK: Cambridge University Press.

36. Mehra, Mandeep R., Frank Ruschitzka, and Amit N. Patel. 2020. "RetractionHydroxychloroquine or Chloroquine with or without a Macrolide for Treatment of COVID-19: A Multinational Registry Analysis." Lancet 395 (10240, P1820):110.

37. Merton, Robert K. 1968. Social Theory and Social Structure, 1968 enlarged edition. New York: Free Press.

38. Mollborn, Stefanie. 2017. Mixed Messages: Norms and Social Control around Teen Sex and Pregnancy. New York: Oxford University Press.

39. Musaraj, Arta. 2020. "The Pandemic and Rhetoric of Organization." Academicus International Scientific Journal, 22:21-29.

40. Parsons, Talcott. 1963. "On the Concept of Political Power." Proceedings of the American Philosophical Society 107 (3):232-262.

41. Parsons, Talcott. 1964. Social Structure and Personality. Glencoe, IL: Free Press.

42. Parsons, Talcott. 1966. "The Political Aspect of Social Structure and Process." Pp. 71-112 in Varieties of Political Theory, edited by D. Easton. Englewood Cliffs, NJ: Prentice-Hall.

43. Pérez-González, Luis. 2020. "'Is Climate Science Taking Over the Science?' A Corpus-based Study of Competing Stances on Bias, Dogma, and Expertise in the Blogosphere." Nature - Humanities \& Social Sciences Communications 7 (92):1-16.

44. Platt, Anthony M. 2009. The Child Savers: The Invention of Delinquency, $40^{\text {th }}$ Anniversary Edition. New Brunswick, NJ: Rutgers University Press. 
45. Popper, Karl. 1945. "The Poverty of Historicism, III." Economica, New Series 12 (46):69-89.

46. Rehberg, K. S., \& Aliberti, S. M. (2020). Personality and Institution-Reflections on paradigmatic structures in Max Weber's thinking. Academicus International Scientific Journal, (21), 131-141.

47. Schmitt, Carl. 2007 [1932]. The Concept of the Political, translated by G. Schwab. Chicago: University of Chicago Press.

48. Sheptycki, James. 2020. "The Politics of Policing a Pandemic Panic." Australian \& New Zealand Journal of Criminology 53 (2):157-173.

49. Slack, Paul. 2020. "Responses to Plague in Early Modern Europe: The Implications of Public Health." Social Research 87 (2):409-428.

50. Spencer, Herbert. 1897. Principles of Sociology, vol. II-3. New York: Appleton.

51. Standing Together for Nutrition Consortium. 2020. "Comment: Impacts of COVID-19 on Childhood Malnutrition and Nutrition-Related Mortality." Lancet, vol. 396, pp. 519-521.

52. Sumner,William Graham. 1906. Folkways. Boston, MA: Ginn and Co.

53. Swedberg, Richard. 1998. Max Weber and the Idea of Economic Sociology. Princeton, NJ: Princeton University Press.

54. Turner, Stephen P. 2003. Liberal Democracy 3.0. Thousand Oaks, CA: Sage.

55. Turner, Stephen P. 2013. "The Blogosphere and Its Enemies: The Case of Oophorectomy." Sociological Review 61 (S2):160-179.

56. Varul, Matthias Zick. 2010. "Talcott Parsons, the Sick Role and Chronic Illness." Body \& Society 16 (2):72-94.

57. Wagner, Helmut R. 1963. "Types of Sociological Theory: Toward a System of Classification." American Sociological Review 28 (5):735-742.

58. Ward, Lester F. 1883. Dynamic Sociology, two volumes. New York: Appleton.

59. Wark, Colin and John F. Galliher. 2007. "Emory Bogardus and the Origins of the Social Distance Scale." American Sociologist 38:383-395.

60. Weber, Max. 1968 [1920]. Economy and Society, volume one, edited by G. Roth and C. Wittich. Berkeley: University of California Press.

61. Weisheit, Ralph A. and John M. Klofas. 1998. "The Public Health Approach to Illicit Drugs." Criminal Justice Review 23 (2):197-207. 